\title{
PENGARUH PEMBELAJARAN PENDIDIKAN KEWARGANEGARAAN MENGGUNAKAN METODE SOSIODRAMA TERHADAP KEPEDULIAN SOSIAL SISWA KELAS V DI SD NEGERI 060898 MEDAN
}

\author{
Derliana Siregar \\ derlianasiregar@gmail.com
}

\begin{abstract}
ABSTRAK
Penelitian ini bertujuan untuk mengetahui pengaruh pembelajaran PKn menggunakan metode sosiodrama terhadap kepedulian sosial siswa kelas V di SD Negeri 060898 Medan Penelitian ini merupakan penelitian eksperimen semu (quasi eksperimen) dengan variabel terikat kepedulian sosial siswa dan variabel bebas metode sosiodrama. Subjek penelitian ini adalah siswa kelas V SD Negeri 060898 Medan, yang berjumlah 57 siswa dan terdiri dari dua kelas. Kelas VA berjumlah 30 siswa sebagai kelompok eksperimen, dan kelas VB 27 siswa sebagai kelompok kontrol. Teknik pengumpulan data yang digunakan dalam penelitian berupa skala, wawancara, observasi, dan dokumentasi. Hasil penelitian ini menunjukkan bahwa pembelajaran PKn menggunakan metode sosiodrama memberikan dampak positif signifikan terhadap kepedulian sosial siswa kelas V SD Negeri 060898 Medan tahun ajaran 2016/ 2017.
\end{abstract}

Kata Kunci: Metode Sosiodrama, Kepedulian Sosial, PKN

\section{PENDAHULUAN}

Pendidikan demokrasi yang terdiri dari, mengembangkan kecerdasan warga negara (civic intelligence), membina tanggung jawab warga negara (civic responsibility), dan mendorong partisipasi warga negara (civic participation). Kecerdasan warganegara yang dikembangkan untuk membentuk warga negara yang baik bukan hanya dalam dimensi rasional, melainkan juga dalam dimensi spiritual, emosional, dan social.

Mata pelajaran PKn sebagai salah satu mata pelajaran yang diajarkan di sekolah, memiliki banyak sekali variasi metode pembelajaran yang dapat digunakan dalam penyampaian materi. Metode yang digunakan tersebut salah satunya adalah sosiodrama. Metode sosidrama dan role playing dapat dikatakan hampir sama artinya, dan dalam pemakaiannya sering disilihgantikan. Syaiful Bahri Djamarah \& Aswan Zain (2006: 88), menjelaskan bahwa sosiodrama pada dasarnya mendramatisasikan tingkah laku yang berhubungan dengan masalah sosial. Berbagai masalah sosial yang terjadi dalam masyarakat memang tidak mudah dijelaskan sekedar menggunakan kata-kata, maka peristiwa tersebut perluntuk didramatisasikan. Metode ini dugunakan untuk memberikan 
pemahaman dan penghayatan tentang masalah-masalah sosial serta mengembangkan kemampuan siswa untuk memecahkannya. Siswa dapat mendramatisasikan tingkah laku, atau ungkapan gerak-gerik wajah seseorang dalam hubungan sosial antar manusia dalam metode ini.

Kenyataan yang didapat peneliti setelah melaksanakan observasi awal dan wawancara di SD Negeri 060898 Medan adalah guru jarang sekali menggunakan metode sosiodrama dalam menyampaikan materi pada pembelajaran PKn. Guru hanya terpaku pada metode ceramah sebagai cara dalam menyampaikan materi.

Berdasarkan beberapa uraian
di atas dapat dilihat bahwa
pembelajaran PKn menggunakan
metode sosiodrama sangat penting
untuk dikuasai oleh guru. Apakah
metode sosiodrama
memperbaiki kepedulian sosial
siswa? Berangkat dari pemikiran
tersebut, penulis tertarik untuk
mengadakan penelitian dengan
mengetengahkan judul "Pengaruh
Pembelajaran Pendidikan
Kewarganegaraan Menggunakan
Metode Sosiodrama Terhadap
Kepedulian Sosial Siswa Di SD
Negeri 060898 Medan".
Berdasarkan uraian latar
belakang di atas, dapat
diidentifikasikan beberapa masalah
yang timbul antara lain:

p-ISSN 2407-4934

e-ISSN 2355-1747
1. Semakin lunturnya kesadaran bahwa manusia adalah makhluk sosial yang harusnya selalu menunjukkan rasa peduli terhadap sesama manusia.

2. Kurangnya sikap peduli sosial siswa di lingkungan sekolah yang dapat dilihat dari rendahnya sikap tepo seliro yang ditunjukkan oleh beberapa siswa.

Tujuan dari penelitian ini adalah untuk mengetahui pengaruh pembelajaran $\mathrm{PKn}$ menggunakan metode sosiodrama terhadap kepedulian sosial siswa kelas V di SD Negeri 060898 Medan.

Secara teoritis hasil penelitian dapat dijadikan salah satu acuan bagi pembangunan nilai-nilai kepedulian sosial bagi siswa SD.

1. Secara Praktis:

a. Bagi siswa: siswa dapat memahami pentingnya nilainilai kepedulian sosial dalam kehidupan. Setelah siswa paham akan pentingya nilainilai kepedulian sosial, diharapkan dalam bertindak dan bersikap selalu mencerminkan nilai-nilai kepedulian sosial.

b. Bagi guru: bagi tenaga pendidik terutama guru, hasil penelitian dapat dijadikan tambahan pengetahuan yang terkait dengan upaya mendidik siswa agar memiliki 
kepedulian sosial. Hasil penelitian dapat membantu untuk meletakkan dasar-dasar nilai kehidupan agar memiliki kepekaan sosial pada saat berinteraksi dengan lingkungan dan masyarakat.

\section{METODE PENELITIAN}

Penelitian ini termasuk ke dalam jenis penelitian eksperimen. Penelitian eksperimen menurut Suharsimi Arikunto (2005:207) adalah penelitian yang dimaksudkan untuk mengetahui ada tidaknya akibat dari sesuatu yang dikenakan pada subjek bebas lainnya.

Penelitian quasi eksperimen ini menggunakan desain Nonequivalent Control Group Design. Menurut Sugiyono (2010: 116), desain ini hampir sama dengan Pre test - Post test Subjek dalam penelitian ini merupakan siswa kelas V SD Negeri 060898 Medan tahun ajaran 2016/2017 yang berjumlah 61 orang anak yang terbagi menjadi 31 siswa kelas V A dan 30 siswa kelas V B. Subjek dalam penelitian ini berupa populasi karena semua siswa kelas V di SD Negeri 060898 Medan dijadikan subjek penelitian. Peneliti menetapkan semua dijadikan subjek penelitian dengan alasan jumlah subjek atau populasi tidak terlalu besar, kurang dari 100 atau lebih dikenal dengan sebutan pendekatan populasi. Seperti pernyataan
Suharsimi Arikunto (2006: 134) yang menyatakan bahwa, subjek kurang dari 100 lebih baik dijadikan subjek penelitian sebagai penelitian populasi.

Penelitian ini terdiri dari dua kelompok untuk diteliti, yaitu kelompok eksperimen dan kelompok kontrol. Penentuan kelompok yang akan menjadi kelompok eksperimen dan kontrol digunakan sistem undian kelas. Berdasarkan hasil undian, maka diperoleh hasil bahwa siswa kelas V A menjadi kelompok eksperimen, sedangkan siswa kelas V B menjadi kelompok kontrol. Waktu penelitian ini dimulai dari bulan Februari sampai dengan Juni 2016, yang meliputi tahap observasi awal sampai dengan penyusunan laporan akhir.

Teknik pengumpulan data adalah cara yang digunakan peneliti untuk memperoleh dan mengumpulkan data. Teknik pengumpulan data tersebut meliputi:

1. Skala

Istilah angket dan skala sering disama artikan dalam penelitian, namun sejatinya keduaanya memiliki fungsi dan tujuan yang berbeda dalam penelitian.

\section{Wawancara}

Wijaya Kusumah \& Dedi Dwitagama (2010: 77) menyatakan bahwa wawancara adalah metode pengumpulan data dalam penelitian dengan mengajukan wawancara secara lisan. 


\section{Dokumentasi}

Dokumentasi merupakan cara untuk mengumpulkan data dengan benda-benda tertulis maupun tidak tertulis (Suharsimi Arikunto, 2006: 158-159). Teknik dokumentasi digunakan untuk memperkuat data yang diperoleh dari hasil observasi. Dokumen yang digunakan berupa RPP dan foto untuk memberikan gambaran secara konkret mengenai kegiatan pembelajaran $\mathrm{PKn}$ menggunakan metode sosiodrama.

Analisis data dalam sebuah penelitian digunakan untuk mengkaji dan mengolah seluruh data yang diperoleh dari berbagai sumber. Data yang diperoleh dalam penelitian ini berupa data kualitatif dan kuantitatif. Data kualitatif didapat dari instrumen yang berupa wawancara, observasi dan dokumentasi. Data kuantitatif diperoleh dari instrumen yang berupa skala kepedulian sosial (pre test dan post test). Instrumen skala tersebut diberikan kepada siswa kelompok eksperimen dan kelompok kontrol.

\section{HASIL DAN PEMBAHASAN}

Jumlah siswa kelas VA sebagai kelompok eksperimen terdiri dari 30 siswa. Kelas VB sebagai kelompok kontrol terdiri dari 27 siswa. Total keseluruhan subjek penelitian ini adalah 57 siswa.

Hasil pengukuran pada kelompok eksperimen peningkatan kepedulian sosial siswa yang dapat dilihat dari peningkatan rerata dari 127,07 menjadi 138,60. tingkat kepedulian sosial siswa sebesar 11,53. Data hasil pengukuran tingkat kepedulian sosial siswa kelompok control diperoleh dari hasil pre test dan post test.

Berdasarkan data yang diperoleh perbandingan data hasil pengukuran tingkat kepedulian sosial siswa kelompok eksperimen-kontrol dilakukan untuk mengetahui perbedaan data antara kelompok eksperimen dan control, bahwa rerata kelompok eksperimen dan kontrol pada data awal masing-masing bernilai 127,07 dan 127,52. Rerata kelompok eksperimen dan kontrol pada data akhir masing-masing bernilai 138,60 dan 130,07.

Tabel 8. Hasil Uji Nomalitas Kelompok Kontrol dan Eksperimen

\begin{tabular}{|l|l|l|l|}
\hline Variabel & $\begin{array}{l}\text { Kolmogoro } \\
\text {-Smirnov }\end{array}$ & $p$ (sig) & Keterangan \\
\hline $\begin{array}{l}\text { Pre test } \\
\text { kontrol }\end{array}$ & 0,554 & 0,919 & Normal \\
\hline $\begin{array}{l}\text { Post test } \\
\text { kontrol }\end{array}$ & 0,492 & 0,969 & Normal \\
\hline $\begin{array}{l}\text { Pre test } \\
\text { eksperimen }\end{array}$ & 0,537 & 0,936 & Normal \\
\hline $\begin{array}{l}\text { Post test } \\
\text { eksperimen }\end{array}$ & 0,537 & 0,936 & Normal \\
\hline
\end{tabular}

Berdasarkan data di atas dapat diketahui bahwa $p$ value (sig) untuk pre test dan post test kelompok kontrol bernilai 0,919 dan 0,969> 0,05 maka H0 diterima, sehingga dapat disimpulkan bahwa data 
diambil dari populasi yang berdistribusi normal. $P$ value (sig) untuk pre test dan post testkelompok eksperimen juga > 0,05 karena keduanya bernilai $\quad 0,936$.

Sehingga dapat ditarik kesimpulan bahwa keempat data tersebut diambil dari populasi yang berdistribusi normal.

Uji homogenitas dilakukan untuk mengetahui data termasuk data homogen atau data yang tidak homogen. Uji homogentias dilakukan denganbantuan program SPSS 17 for windows dengan uji Levene. Hasil uji homogenitas dapat dilihat pada tabel berikut ini.

Tabel 9. Hasil Uji Homogenitas
Kelompok Kontrol dan
Eksperimen
\begin{tabular}{|c|c|c|c|}
\hline Variabel & Levene & $p($ sig $)$ & Keterangan \\
\hline Pre test & 0,010 & 0,920 & homogen \\
\hline Post test & 0,218 & 0,643 & homogen \\
\hline
\end{tabular}

Berdasarkan data di atas dapat dilihat bahwa $p$ value (sig) untuk pre test kelompok kontrol dan eksperimen bernilai 0,920 . Hal ini berarti bahwa $\mathrm{H} 0$ diterima karena $p$ value (sig) > 0,05, sehingga dapat disimpulkan bahwa data yang diteliti termasuk data yang homogen. $P$ value (sig) pada post test kelompok kontrol dan eksperimen bernilai 0,643 yang berarti > 0,05 sehingga dapat disimpulkan bahwa data tersebut homogen.
Tujuan dilakukan uji $\mathrm{t}$ pada pre test kelompok eksperimen dan kontrol adalah untuk mengetahui kondisi awal siswa. Ada perbedaan antara nilai pre test kelompok eksperimen dan kontrol. Kesimpulannya adalah sebelum diberikan treatment, antara kelompok eksperimen dan kontrol memiliki tingkat kepedulian sosial yang sama. Nilai post test kelompok eksperimenkontrol adalah 0,02 yang berarti < 0,05 . Berdasarkan data tersebut maka dapat dikatakan bahwa terdapat perbedaan signifikan antara nilai post test kelompok eksperimen dan kontrol. Dengan demikian dapat disimpulkan bahwa antara kelompok eksperimen dan kontrol memiliki tingkat kepedulian sosial yang berbeda setelah diberikan suatu perlakuan (treatment), yang berarti pembelajaran PKn menggunakan metode sosiodrama berpengaruh signifikan terhadap kepedulian sosial siswa.

Berdasarkan hasil pengujian dengan menggunakan uji t, diketahui bahwa terdapat perbedaan tingkat kepedulian sosial siswa yang diajar menggunakan metode sosiodrama dengan siswa yang diajar dengan metode konvensional. Kelompok eksperimen yang pada pembelajaran PKn menggunakan metode sosiodrama memiliki rerata nilai yang lebih besar jika dibandingkan dengan kelompok kontrol yang menggunakan 
metode konvensional. Perbedaan rerata ini bisa dikatakan sebagai akibat dari metode yang digunakan pada kelompok eksperimen dan kontrol. Hasil pengujian hipotesis yang telah dilakukan diperkuat dengan adanya hasil wawancara oleh guru dan siswa, serta hasil observasi. Berdasarkan hasil wawancara dengan guru kelas VA, penggunaan metode sosiodrama dalam pembelajaran PKn dapat meningkatkan kepedulian sosial siswa. Metode sosiodrama mengajarkan siswa untuk saling membantu, menolong, dan menghargai.

Berdasarkan penuturan guru kelas VA, setelah menggunakan metode sosiodrama siswa lebih bisa menghargai teman dan tidak memilihmilih dalam pembentukan kelompok. Guru kelas tersebut juga menuturkan bahwa, metode sosiodrama layak untuk dikembangkan tidak hanya pada pembelajaran PKn tetapi pada mata pelajaran yang lain karena memiliki banyak manfaat bagi siswa. Siswa terlihat antusias dalam menjalani pembelajaran selama proses pembelajaran berlangsung. Siswa tampak senang dengan metode sosiodrama yang diterapkan. Berdasarkan wawancara yang dilakukan dengan siswa diperoleh hasil bahwa, siswa senang dengan penggunaan metode sosiodrama karena dapat bekerjasama dengan teman lain, menambah pengalaman, dan lebih bersemangat dalam menjalani pembelajaran.

\section{SIMPULAN}

Berdasarkan hasil penelitian dan analisis data yang telah dilakukan maka dapat ditarik kesimpulan sebagai berikut, pembelajaran PKn dengan menggunakan metode sosiodrama memberikan dampak positif yang signifikan terhadap kepedulian sosial siswa kelas V SD Negeri 060898 Medan tahun ajaran 2016/2017. Hal tersebut ditunjukkan dengan uji t pada post test kelompok eksperimen kontrol yang menunjukkan perbedaan signifikan antara post test kelompok eksperimen dan kontrol setelah diberikan treatment.

Berdasarkan kesimpulan dari penelitian ini, maka saran yang dapat disampaikan adalah sebagai berikut.

1. Bagi guru, disarankan untuk menerapkan metode sosiodrama pada mata pelajaran PKn materi keputusan pribadi-kelompok dan bentuk-bentuk keputusan bersama. Hal ini dikarenakan adanya dampak positif yang signifikan dalam penerapan metode ini terhadap kepedulian sosial siswa.

2. Bagi pembaca, disarankan untuk mengadakan penelitian lebih lanjut untuk melengkapi kekurangan yang terdapat pada penelitian ini, sehingga hasil penelitian 
berikutnya dapat digunakan sebagai referensi akurat.

\section{DAFTAR RUJUKAN}

Abu Ahmadi \& Nur Uhbiyati. 2001. Ilmu Pendidikan. Jakarta: Rineka Cipta.

Agus Wibowo. 2012. Pendidikan Karakter. Yogyakarta: Pustaka Pelajar.

Amirulloh Syarbini. 2012. Buku Pintar Pendidikan Karakter. Jakarta: as@_ prima.

Arif Rohman. 2009. Memahami Pendidikan \& Ilmu Pendidikan. Yogyakarta: Laksbang Mediatama.

Ary H. Gunawan. 2000. Sosiologi Pendididkan. Jakarta: Rineka Cipta.

B. Suryosubroto. 2002. Proses Belajar Mengajar di Sekolah. Jakarta: Rineka Cipta.

Bahanuddin Salam. 2002. Pengantar Pedagogik. Jakarta: Rineka Cipta.

Buchari Alma, dkk. 2010. Pembelajaran Studi Sosial. Bandung: Alfabeta.

Darmiyati Zuchdi. 2011. Pendidikan Karakter dalam Prespektif Teori dan Praktek. Yogyakarta: UNY Press.
DinnWahyudin, dkk. 2008. Pengantar Pendidikan. Jakarta: Universitas Terbuka.

Elly M. Setiadi, Kama A. Hakam, Ridwan Effendi. 2012. Ilmu Sosial dan Budaya Dasar. Jakarta: Kencana.

Fathurrohman \& Wuri Wuryandari. 2011. Pembelajaran PKn di Sekolah Dasar. Yogyakarta: Nuha Litera.

Fuad Ihsan. 2003. Dasar-Dasar Kependidikan. Jakarta: Rineka Cipta.

Hera Lestari Mikarsa, Agus Taufik \& Puji Lestari Prianti. 2008. Pendidikan Anak SD. Jakarta: Universitas Terbuka.

J.J. Hasibuan \& Moedjiono. 2006. Proses Belajar Mengajar. Bandung: Rosda.

J.K. Moh. Nazir. (2003). Metode Penelitian. Jakarta: Ghalia Indonesia. 